\section{RB005014 - a sugarcane cultivar with high tillering and agroindustrial yield}

\section{Monalisa Sampaio Carneiro ${ }^{1 *}$, Roberto Giacomini Chapola ${ }^{1}$, Antonio Ribeiro Fernandes Junior ${ }^{2}$, Danilo Eduardo Cursi ${ }^{1}$, Thiago Willian Almeida Balsalobre ${ }^{1}$ and Hermann Paulo Hoffmann ${ }^{1}$}

\begin{abstract}
RB005014 was developed for the Brazilian central-south region, for harvesting between July and September and planting on soils that have moderate or higher fertility levels. It has high tillering, high sucrose yield, excellent ratooning ability after mechanical harvesting, resistance to the main diseases and carries the Bru1 gene of brown rust resistance.
\end{abstract}

Keywords: Saccharum spp., improvement, disease resistance.

\section{INTRODUCTION}

Modern sugarcane cultivars have a complex genome, due to large genome size arround $10 \mathrm{~Gb}$, a variable ploidy level and constant aneuploidy resulting in highly heterozygous hybrids (Vieira et al. 2018). Cultivated sugarcane is a vegetatively propagated crop, which takes approximately 8 to 12 years to improve and release more productive cultivars.

The Sugarcane Breeding Program of the Federal University of São Carlos - PMGCA/UFSCar (www.ridesaufscar.com.br) is part of the Inter-University Network for the Development of Sugarcane Industry - RIDESA (www.ridesa. com.br). In over 40 years, 94 RB sugarcane cultivars were released, currently planted on nearly $64 \%$ of the sugarcane growing area in Brazil (Daros et al. 2015, Chapola et al. 2016).

The RIDESA network aims to develop high-yielding cultivars with a high sucrose content, resistance to the main diseases and adapted to different climate and soil conditions (Carneiro et al. 2016, Daros et al. 2018). Furthermore, the stability of cultivar yields in mechanical planting and harvesting systems has been a challenge and concern for RIDESA (Daros et al. 2018). In this context, the high tillering and excellent ratooning ability of RB005014, even under mechanical harvesting, indicate the cultivar as promising. Moreover, this sugarcane cultivar is suitable for mechanized planting and has good resistance levels against the major sugarcane diseases.

\section{PEDIGREE AND BREEDING METHOD}

Cultivar RB005014 was derived from a biparental cross of the full-sib genotypes SP80-1816 x RB855536 (Figure 1). At the beginning of the year
Crop Breeding and Applied Biotechnology 19: 230-234, 2019 Brazilian Society of Plant Breeding. Printed in Brazil http://dx.doi.org/10.1590/198470332019v19n2c32 
2000 , the cross was carried out at the experimental site Estação de Floração e Cruzamento da Serra do Ouro (lat 9o $13^{\prime} \mathrm{S}$, long 350 50' W, alt $450 \mathrm{~m}$ asl), in the municipality of Murici, Alagoas, of the Federal University of Alagoas. Later in the same year, sugarcane caryopses were planted and germinated in a greenhouse at the experimental station of the Federal University of São Carlos (lat $22^{\circ} 21^{\prime}$ S, long $47^{\circ} 23^{\prime} \mathrm{W}$, alt $620 \mathrm{~m}$ asl), in the city of Araras, São Paulo. Thereafter the sugarcane plantlets were individualized and planted at an experimental field in order to establish the first selection stage (T1). In this phase, each genotype, represented by a single clump, was mass-selected in the first ratoon crop for general morphological criteria like as higher Brix, resistance to the main diseases, absence of flowering, stalk number and reduced bagasse pith (Morais et al. 2015).

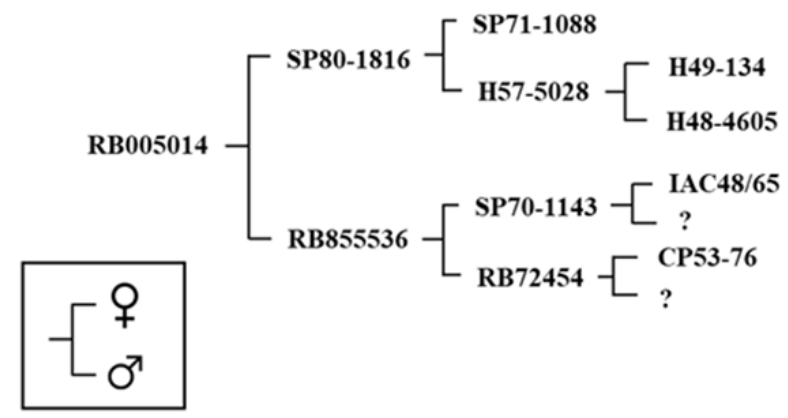

Figure 1. Pedigree of sugarcane cultivar RB005014.

The clones selected in the T1 stage were taken to the second selection stage (T2), which also had standard commercial cultivars for comparison of yields. In this phase, the genotypes were grown at two locations in the state of São Paulo: Araras (lat $22^{\circ} 21^{\prime} \mathrm{S}$, long $47^{\circ} 23^{\prime} \mathrm{W}$, alt $620 \mathrm{~m}$ asl) and Valparaiso (lat $21^{\circ} 13^{\prime} \mathrm{S}$, long $50^{\circ} 52^{\prime} \mathrm{W}$, alt 439 $\mathrm{m}$ asl). The experiment in $\mathrm{T} 2$ stage was evaluated in an augmented randomized incomplete block design (Federer 1956), with plots consisting of two 2.5-m rows, with one replication. Genotypes in T2 stage were assessed in plant cane and ratoon crops likewise in T1 stage, plus the variables stalk weight per plot (WP) and kilogram brix per plot (KBP) (Kang et al. 1983). Clones selected during T2 stage advanced for the third selection stage (T3) as described by Carneiro et al., (2016). In T3, clones were evaluated at three sites under different climate and soil conditions, in different regions of Sao Paulo state (Tarumã-SP (lat $22^{\circ} 44^{\prime} \mathrm{S}$, long $50^{\circ} 34^{\prime} \mathrm{W}$, alt $429 \mathrm{~m}$ asl), Nova Europa-SP (lat $21^{\circ} 46^{\prime} \mathrm{S}$, long $48^{\circ} 33^{\prime} \mathrm{W}$, alt $502 \mathrm{~m}$ asl), Barra Bonita-SP (lat $22^{\circ} 28^{\prime} \mathrm{S}$, long $48^{\circ} 33^{\prime} \mathrm{W}$, alt $526 \mathrm{~m}$ asl). The selection in T3 stage was performed considering the performance of the clones across all evaluated environments and both plant and ratoon crops. The selection criteria were utilized sucrose content in sugarcane (PC, in \%) and kilogram pol per plot (KPP).

The selected genotypes were planted in the experimentation stage (ES), in which they were assessed in 15 fields trials allocated in the diverse in regions of São Paulo and Mato Grosso do Sul: Tarumã-SP (lat $22^{\circ} 44^{\prime} \mathrm{S}$, long $50^{\circ} 34^{\prime}$ W, alt $429 \mathrm{~m}$ asl), Nova Europa-SP (lat $21^{\circ} 46^{\prime} \mathrm{S}$, long $48^{\circ} 33^{\prime} \mathrm{W}$, alt $502 \mathrm{~m}$ asl), Barra Bonita-SP (lat $22^{\circ} 28^{\prime} \mathrm{S}$, long $48^{\circ} 33^{\prime} \mathrm{W}$, alt $526 \mathrm{~m}$ asl), Guaíra-SP (lat $20^{\circ} 19^{\prime} \mathrm{S}$, long $48^{\circ} 18^{\prime} \mathrm{W}$, alt 518 asl), Pradópolis-SP (lat $21^{\circ} 21^{\prime} \mathrm{S}$, long $48^{\circ}$ $4^{\prime} \mathrm{W}$, alt 533 asl), Promissão-SP (lat $21^{\circ} 32^{\prime} \mathrm{S}$, long $49^{\circ} 51^{\prime} \mathrm{W}$, alt 425 asl), Valparaíso-SP (lat $21^{\circ} 13^{\prime} \mathrm{S}$, long $50^{\circ} 52^{\prime}$ W, alt $439 \mathrm{~m}$ asl), Olímpia-SP (lat $20^{\circ} 44^{\prime} \mathrm{S}, 48^{\circ} 54^{\prime} \mathrm{W}$, alt 480 asl), Tanabi-SP (lat $20^{\circ} 37^{\prime} \mathrm{S}$, long $49^{\circ} 39^{\prime} \mathrm{W}$, alt $521 \mathrm{~m}$ asl), Paraguaçu Paulista-SP (lat $22^{\circ} 24^{\prime} \mathrm{S}$, long $50^{\circ} 34^{\prime} \mathrm{W}$, alt $509 \mathrm{~m}$ asl), Piracicaba-SP (lat $22^{\circ} 43^{\prime} \mathrm{S}$, long $47^{\circ} 38^{\prime} \mathrm{W}$, alt $526 \mathrm{~m}$ asl), Orindiúva-SP (lat $20^{\circ} 11^{\prime} \mathrm{S}$, long $49^{\circ} 21^{\prime} \mathrm{W}$, alt $487 \mathrm{~m}$ asl), Guariba-SP (lat $21^{\circ} 21^{\prime} \mathrm{S}$, long $48^{\circ} 13^{\prime} \mathrm{W}$, alt $649 \mathrm{~m}$ asl), Sandovalina-SP (lat $22^{\circ} 27^{\prime} \mathrm{S}, 51^{\circ} 45^{\prime} \mathrm{W}$, alt $383 \mathrm{~m}$ asl), Angélica-MS (lat $22^{\circ} 9^{\prime} \mathrm{S}$, long $53^{\circ} 46^{\prime} \mathrm{W}$, alt 366 $\mathrm{m}$ asl)), recording the data of three to four cycles. The fields tests were established in the randomized block ( 3 or 4 replicates), with standard commercial cultivars as controls, alocated in the blocks. The traits assessed were sucrose content in sugarcane (PC, in \%), tons of stalks per hectare (TSH), tons of pol per hectare (TPH), and fiber content (in, \%). The clone adaptability and stability were estimated according by Eberhart and Russell (1966). The selected genotypes of ES were evaluated to maturation curve, according to the sucrose content in sugarcane (PC, in \%).

\section{PERFORMANCE}

Cultivar RB005014 has an intermediate development cycle and upright growth habit. The stalks have a medium diameter, a high amount of wax, a greyish green color and the leaf blades are green and waxy. The tillering capacity in plant and ratoon crops is high, with excellent canopy cover, high ratooning ability even under mechanical harvesting, and sugarcane longevity (several harvests from one planting). In addition, cultivar RB005014 has a high agro- 
industrial yield, yield stability and good fiber content. Under the conditions of central-south region of Brazil, the recommended harvest time for RB005014 is the middle of the growing season, between July and September (Figure 2). Under these conditions, cultivar RB005014 rarely flowers and produces little or no pith.

Cultivar RB005014 had responsiveness to improvements soil and climatic conditions. Considering the standard commercial cultivar (RB867515), the cultivar RB005014 had greater agricultural yield (TSH) in the intermediate to favorable environments, whereas in restricted environments presented TSH lower yields than standard commercial (Figure 3). The RB005014 was evaluated in precommercial areas, and RB005014 cultivar recommendation is for favorable and intermediate soil and climatic conditions, according to the classification of Prado (2008).

Cultivar RB005014 produced an agricultural yield (TSH) of more than $119 \mathrm{~T} \mathrm{ha}^{-1}$ and a cane sucrose content (PC, in \%) of approximately $15.5 \%$. The performance of this cultivar with regard to the agroindustrial yield (in tons of pol per hectare - TPH) was excellent, higher to that of commercial standard cultivars of intermediate/late maturation, considering the mean data of 13 field tests with three to four harvests each (Figure 4).

\section{OTHER CHARACTERISTICS}

\section{Disease reaction}

Cultivar RB005014 was subjected to tests of artificial inoculation and natural infection with the main sugarcane diseases, together with other genotypes. These tests assessed the reaction of clones and cultivars against these diseases under the conditions of central-south region of Brazil.

Disease evaluation under natural infection conditions were performed in areas with weather conditions to pathogen occurrence and, consequently, with high inoculum pressure. Thereby, we evaluated under natural infection conditions the main sugarcane diseases; orange rust (Puccinia kuehnii), brown rust (Puccinia melanocephala), smut (Sporisorium scitamineum), leaf mosaic (sugarcane mosaic virus) and leaf scald (Xanthomonas albilineans). The evaluation is based on the number of infected clumps (\% incidence) for smut, mosaic and scald, and based on the leaf area percentage with symptoms (\% severity) for orange and brown rusts (Amorim et al. 1987).

Greenhouse tests of artificial inoculation with smut fungus spores and contamination with mosaic virus suspension were carried out, as described by Matsuoka (1979). The evaluation was followed by scale for each disease, which considers the amount of infected plants (\% incidence) and the clones were categorized as resistant, intermediate or susceptible. The results in both tests indicated RB005014 as highly resistant to the diseases evaluated (Table 1); therefore, it is recommended for planting without restriction.

The brown rust resistance in modern sugarcane cultivars is largely due to the Bru1 gene presence. Thereby, to verify if cultivar RB005014 has this resitance gene, the genomic DNA was extracted as described by Aljanabi et al. (1999) 


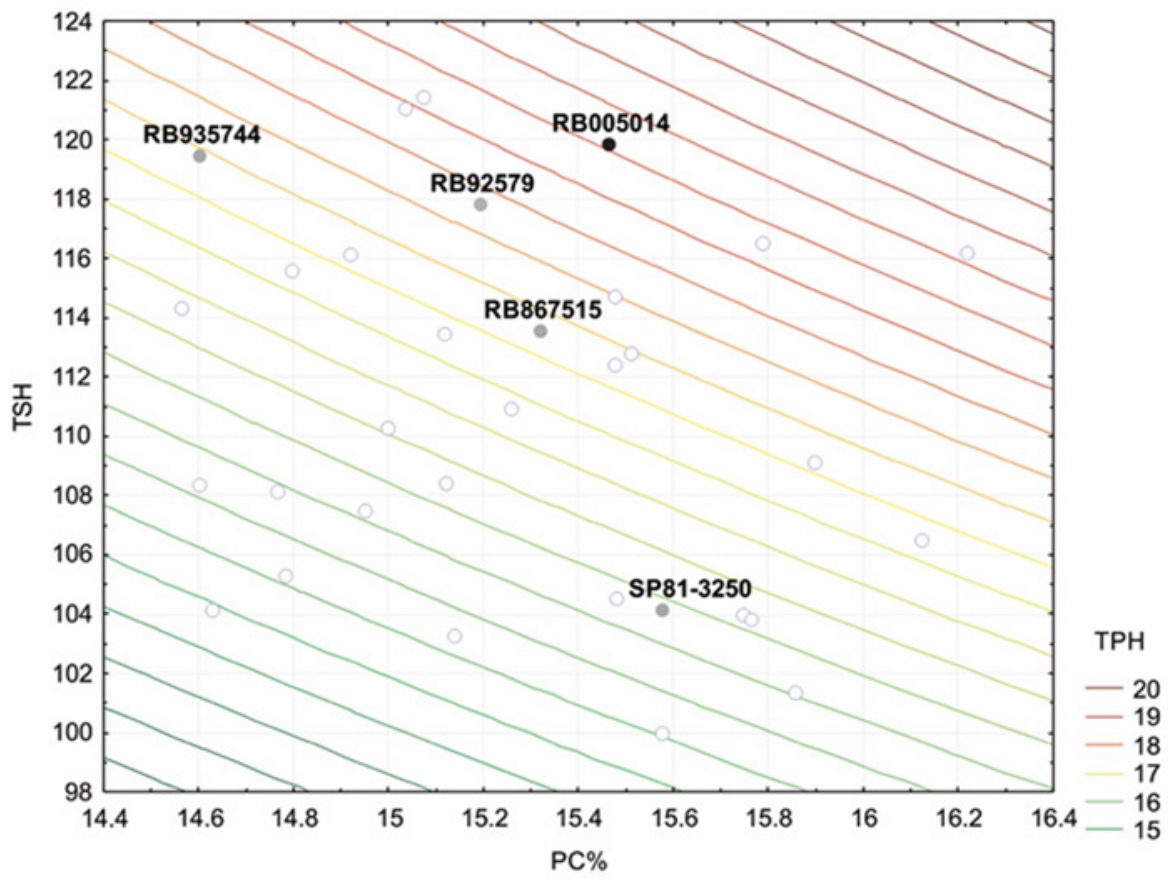

Figure 4. Isoquants of mean tons of pol per hectare (TPH) in function of sucrose content (PC in \%), in sugarcane and tons of stalks per hectare (TSH) in 13 experiments. In the black circle, cultivar RB005014 is compared with standard commercial cultivars (gray circles) and clones (void circles).

and after that the presence of the $B r u 1$ gene was detected using the molecular markers $\mathrm{R} 12 \mathrm{H} 16$ and 9O20-F4-Rsal (Costet et al. 2012). The PCR reactions and amplification conditions were carried out as proposed by Costet et al. (2012). The result showed that Bru1 gene was present in cultivar RB005014, attested by the positive diagnosis of the two molecular markers evaluated (haplotype 1).

\section{BASIC SEED MAINTENANCE AND DISTRIBUTION}

The samples of cultivar RB005014 are keepting and distributed by the Sugarcane Breeding Program (https:// www.ridesaufscar.com.br/) of the Department of Biotechnology, Plant and Animal Production, Center of Agricultural Sciences, Federal University of São Carlos, Araras, São Paulo, Brazil.

\section{REFERENCES}

Aljanabi S, Forget L and Dookun A (1999) An improved and rapid protocol for the isolation of polysaccharide-and polyphenol-free sugarcane DNA. Plant Molecular Biology Reporter 17: 281-281.

Amorim L, Bergamin-filho A, Sanguino A, Cardoso C, Moraes VA and Fernandes CR (1987) Metodologia de avaliação da ferrugem da canade-açúcar (Puccinia melanocephala). Boletim Técnico COPERSUCAR 39: 13-16.
Table 1. Reaction of sugarcane cultivar RB005014 to diseases in the central-south region of Brazil

\begin{tabular}{lc}
\hline Disease & Cultivar RB005014 \\
\hline Smut & $\mathrm{R}$ \\
Brown rust & $\mathrm{R}^{+}$ \\
Orange rust & $\mathrm{R}$ \\
Mosaic & $\mathrm{R}$ \\
Leaf Scald & $\mathrm{R}$ \\
\hline
\end{tabular}

$\mathrm{R}=$ resistant; + = Presence of molecular markers Bru1 (haplotype 1: presence of the two markers R12H16 and 9O20-F4-Rsal)
Carneiro MS, Chapola RG, Fernandes Júnior AR, Cursi DE, Barreto FZ, Balsalobre TWA and Hoffmann HP (2016) RB975242 and RB975201 - Late maturation sugarcane varieties. Crop Breeding and Applied Biotechnology 16: 365-370.

Chapola RG, Fernandes Júnior AR, Cursi DE and Hoffmann HP (2016) Censo de variedades de cana-de-açúcar nos estados de São Paulo e Mato Grosso do Sul em 2015. STAB 34: 40-42.

Costet L, Le Cunff L, Royaert S, Raboin LM, Hervouet C, Toubi L, Telismart H, Garsmeur O, Rousselle Y, Pauquet J, Nibouche S, Glaszmann JC, 


\section{MS Carneiro et al.}

Hoarau JY and D'Hont A (2012) Haplotype structure around Bru1 reveals a narrow genetic basis for brown rust resistance in modern sugarcane cultivars. Theoretical and Applied Genetics 125: 825-36.

Daros E, Oliveira RA and Barbosa GVS (2015) 45 anos de variedades RB de cana-de-açúcar: 25 anos de Ridesa. Graciosa, Curitiba, 156p.

Daros E, Oliveira RA, Zambon JLC, Filho JCB, Brasileiro BP, Ido OT, Ruaro L and Weber H (2017) RB036088 - a sugarcane cultivar for mechanical planting and harvesting. Crop Breeding and Applied Biotechnology 17: $84-88$.

Daros E, Oliveira RA, Zambon JLC, Filho JCB, Brasileiro BP, Ido OT, Ruaro L and Weber H (2018) RB036066 - a sugarcane cultivar with high adaptability and yield stability to Brazilian South-Central region. Crop Breeding and Applied Biotechnology 18: 325-329.

Eberhart SA and Russell WA (1966) Stability parameters for comparing varieties. Crop Science 6: 36-40.

Federer WT (1956) Augmented (or hoonuiaku) designs. Hawaian Planters' Record 55: 191-208.
Kang MS, Miller JD and Tai PYP (1983) Genetic and phenotypic path analysis and heritability in sugarcane. Crop Science 23: 643-647.

Matsuoka S (1979) Método para pré-testagem de clones de cana-deaçúcar ao carvão e ao mosaico conjuntamente. In I congresso nacional da sociedade dos técnicos açucareiros e alcooleiros do brasil. STAB, Maceió, p. 231-233.

Morais L K, Aguiar MS, Silva PA, Câmara TMM, Cursi DE, Fernandes Júnior AR, Chapola RG, Carneiro MS and Bespalhok Filho JC (2015) Breeding of sugarcane. In Cruz VMV and Dierig DA (eds) Industrial crops: breeding for bioenergy and bioproducts. Springer, New York, p. 29-42.

Prado H (2008) Pedologia fácil: aplicações na agricultura. Hélio do Prado, Piracicaba, 45p.

Vieira MLC, Almeida CB, Oliveira CA, Tacuatiá LO, Munhoz CF, Cauz-Santos LA, Pinto LR, Monteiro-Vitorello CB, Xavier MA and Forni-Martins ER (2018) Revisiting meiosis in sugarcane: chromosomal irregularities and the prevalence of bivalent configurations. Frontiers in Plant Science 9: 213 